\title{
Recent Progress in Carbon Dioxide Electrolyzer Using Gas Diffusion Electrode
}

\author{
Junhyeong Kim, Sang Hyun Ahn ${ }^{\dagger}$ \\ School of Chemical Engineering and Material Science, Chung-Ang University, \\ Seoul, Republic of Korea \\ 기체 확산 전극을 이용한 이산화탄소 전해조의 연구동향 \\ 김준형, 안상현 ${ }^{\dagger}$ \\ 중앙대학교 화학신소재공학부
}

(Received February 19 2021; Accepted February 24 2021)

\begin{abstract}
s
As the global warming has been accelerated due to the indiscreet use of fossil fuels, various efforts are conducted to decrease the $\mathrm{CO}_{2}$ concentration in atmosphere. The electrochemical $\mathrm{CO}_{2}$ reduction has been recognized as the eco-friendly technology that $\mathrm{CO}_{2}$ can be converted to useful products. However, for the commercialization of this technology, it is necessary to acquire the minimum $200 \mathrm{~mA} / \mathrm{cm}^{2}$ of current density with high product selectivity. Unlike the conventional $\mathrm{H}$-type cell system, the gas-phase $\mathrm{CO}_{2}$ electrolysis system facilitates much faster reactant supply into electrode which can overcome the $\mathrm{CO}_{2}$ masstransport limitation. In this review, we introduce the gas-phase $\mathrm{CO}_{2}$ electrolysis technology, according to the electrolyzer configuration. In the case of gas-phase $\mathrm{CO}_{2}$ electrolyzer containing catholyte layer has an advantage of facile formation of triple-phase boundary for the reaction, resulting in excellent operating stability. On the other hand, the membrane electrode assembly-based $\mathrm{CO}_{2}$ electrolyzer shows the lower ohmic resistance than other configurations that can reduce the operating cell voltage. These investigations can accelerate the commercialization of $\mathrm{CO}_{2}$ electrolysis system.
\end{abstract}

Keywords: Electrochemical $\mathrm{CO}_{2}$ conversion, $\mathrm{CO}_{2}$ electrolyzer, Gas diffusion electrode, Gas-phase $\mathrm{CO}_{2}$ supply

${ }^{\dagger}$ Corresponding Author: Sang Hyun Ahn

E-mail: shahn@cau.ac.kr 


\section{1. 서론}

최근 무분별한 화석 연료 사용으로 인하여 대기중 이 산화탄소의 농도가 급증하고 이에 따라 지구온난화 문 제가 심각해지고 있다. ${ }^{1,2)}$ 이러한 환경 문제를 해결하 고자, 대기중 이산화탄소 농도를 감축하고 나아가 이 산화탄소를 활용하여 실생활에 유용한 연료를 생산하 기 위한 많은 노력들이 진행되고 있다. 그 중에서도, 전 기화학적 이산화탄소 전환 기술은 포집된 이산화탄소 를 전기화학적으로 저감함과 동시에 $\mathrm{CO}, \mathrm{CH}_{4}, \mathrm{CH}_{3} \mathrm{OH}$, $\mathrm{HCOOH}, \mathrm{C}_{2} \mathrm{H}_{4}$ 과 같은 유용한 연료로 전환할 수 있는 친환경적 에너지 생산 기술이라 할 수 있다. ${ }^{3)}$ 이러한 전 기화학적 이산화탄소 전환 기술을 상업적으로 활용하기 위해서는 $90 \%$ 이상의 생성물에 대한 이산화탄소 전환 효율과 함께 대략 $200 \mathrm{~mA} / \mathrm{cm}^{2}$ 이상의 생성물에 대한 전류 밀도가 확보되어야 한다. ${ }^{4)}$ 하지만, 기존의 $\mathrm{H}$-type 이산화탄소 전해조의 경우, 수용액에 대한 이산화탄소 의 낮은 용해도가 이산화탄소 전해조의 성능 증대를 방 해하는 가장 큰 문제점으로 꼽히고 있다. 수용액에 대한 낮은 이산화탄소의 용해도로 인하여 전극 표면으로의 물질 전달이 제한되고, 결과적으로 최대 $35 \mathrm{~mA} / \mathrm{cm}^{2}$ 의 낮은 전류 밀도만 확보 가능하다. 또한, 기존의 $\mathrm{H}$-type 전해조 구조상, 음극과 양극 사이에 고분자 전해질막과 전해질의 존재로 인하여 높은 ohmic 과전압이 발생한 다. 이러한 문제를 보완하고자, 기체 형태의 이산화탄소 를 전극에 직접 공급이 가능한 전해조 개발에 대한 연구 가 활발히 진행되고 있고, gas diffusion layer (GDL) 을 활용하여 원활한 이산화탄소 기체의 유입과 생성물 의 배출을 기대할 수 있다. ${ }^{4)}$ Fig. 1은 이산화탄소 전해 조에 가해지는 전류 밀도에 따른 전극 표면에서의 영향 을 보여주고 있다. 이산화탄소의 전기화학적 환원 반응 은 proton을 필요로 한다. ${ }^{4}$ 낮은 전류 구간에서는 전해 질에 존재하는 hydronium ion이 proton의 역할을 대 신하지만, 가해지는 전류가 증가함에 따라 hydronium ion의 농도는 감소하여 0 으로 수렴한다. 전극 표면에 존 재하는 hydronium ion이 모두 고갈되었을 때, 물 분해 반응을 통해 생성된 proton이 이산화탄소 환원 반응에
참여한다. 기존의 H-type형태의 전해조의 경우, 이산 화탄소의 낮은 용해도로 인하여 전류 밀도가 증가할수 록 전극 표면에서의 이산화탄소 농도가 급격하게 감소 한다. 결과적으로 고전류 영역으로 갈수록 경쟁 반응인 수소 발생 반응이 우세하게 진행된다. 반면에, 기체 확 산 층을 활용한 경우, 기체 형태의 이산화탄소가 수용액 에 용해된 것보다 높은 확산계수를 보이기 때문에 전극 표면으로의 물질 전달이 우수하여 높은 이산화탄소 농 도를 유지할 수 있다. 결과적으로, GDL 활용 시 고전류 영역에서도 높은 생성물 선택도와 함께 우수한 이산화 탄소 전해조 성능을 나타낼 수 있다. 본 논문에서는, 최 근 연구되고 있는 이산화탄소 기체의 직접적인 공급이 가능한 전해조와 그의 구조에 따른 개발 동향을 살펴보 고자 한다.

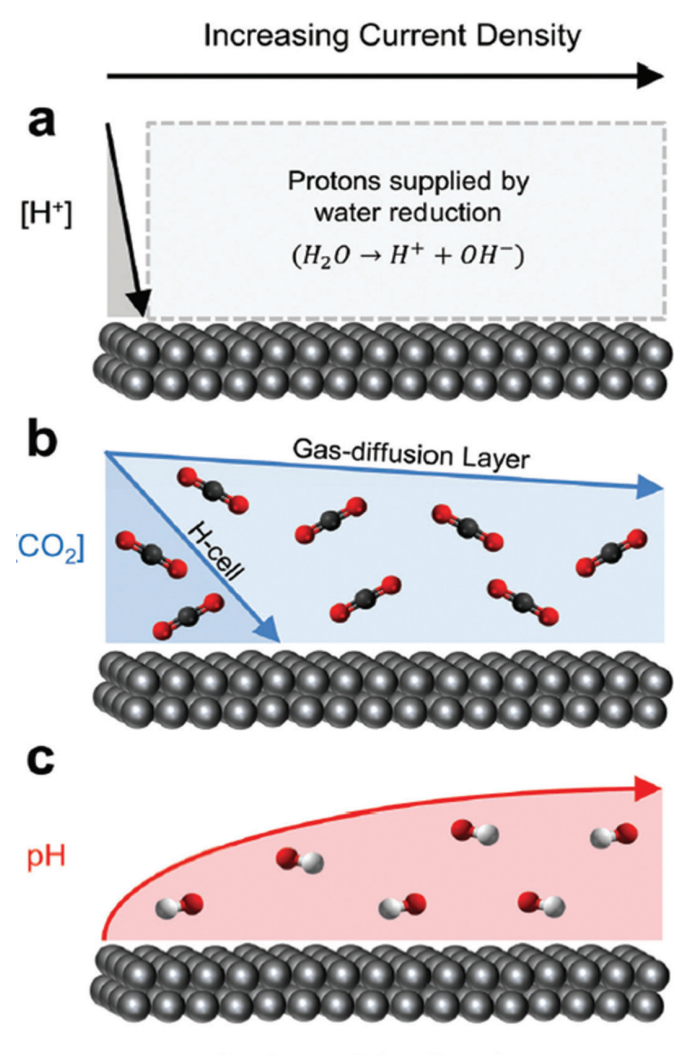

\section{Surface of the Catalyst}

Fig. 1. 전극 표면에서의 전류밀도에 따른 변화: (a) Proton 농도, (b) $\mathrm{CO}_{2}$ 농도, (c) pH Reproduced by Kim et al. Energy \& Environ Sci 2019;12:1442-53, with permission of Royal Society of Chemistry Publication [4]. 


\section{2. 본문}

\section{2-1. Catholyte층을 포함하는 이산화탄소 전해조}

Gas diffusion electrode (GDE)는 다공성의 GDL과 촉매 물질이 결합된 전극 형태으로써 연료전지나 수전 해 기술에서 이미 많은 연구가 진행되었다. 다공성 형태 의 전극 구조는 원활한 반응물의 유입 및 생성물의 배출 할 뿐만 아니라 넓은 활성면적을 기대할 수 있다. 또한, $\mathrm{GDE}$ 를 활용함으로써 기체 형태의 이산화탄소 공급이 가능해지고, 전극 표면의 이산화탄소 농도를 높은 수치 로 유지할 수 있다. 2018년 Curtis P. Berlinguette 연 구팀의 연구 결과에 따르면, 수용액에 용해된 이산화탄 소의 확산 계수는 $0.0016 \mathrm{~mm}^{2} / \mathrm{s}$ 인 반면, 가습된 이산화 탄소 기체의 경우 $16 \mathrm{~mm}^{2} / \mathrm{s}$ 로 대략 10,000 배 더 큰 것 으로 나타났다 (Fig. 2). ${ }^{5}$ 두 종류의 이산화탄소 전해조 의 성능을 비교해본 결과, $-3.0 \mathrm{~V}$ 의 구동전압 조건에서 기체 공급 기반의 이산화탄소 전해조에서 대략 2 배 더 높은 활성을 보였다. 이를 통해서, GDE의 활용이 이산 화탄소 전해 기술의 상용화를 한발 더 앞당길 수 있다.

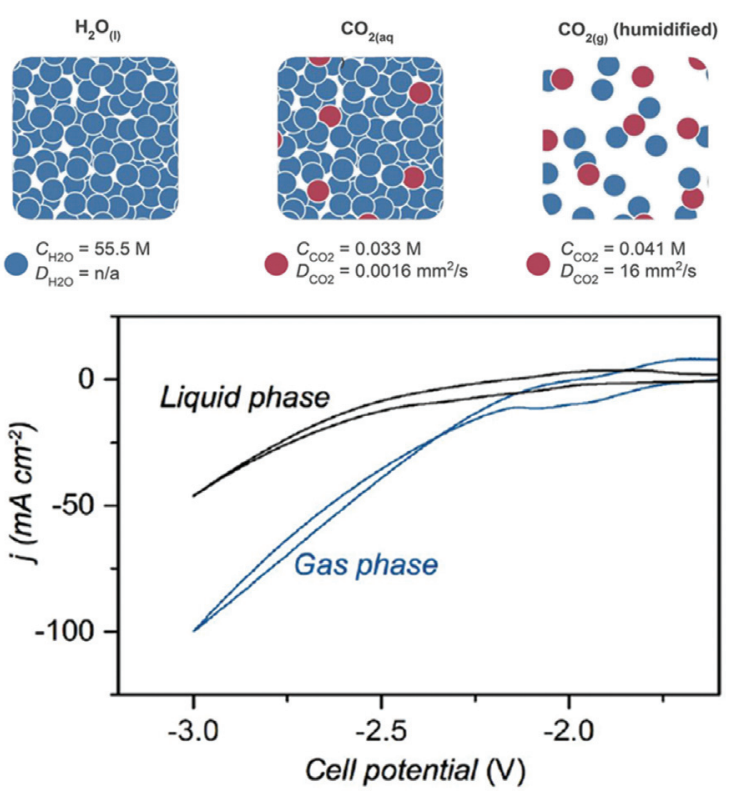

Fig. 2. 이산화탄소 반응물의 형태에 따른 전해조 성능 차이. Reproduced from Kim et al. Acc Chem Res 2018;51: 910-8, with permission of American Chemical Society Publication [5].

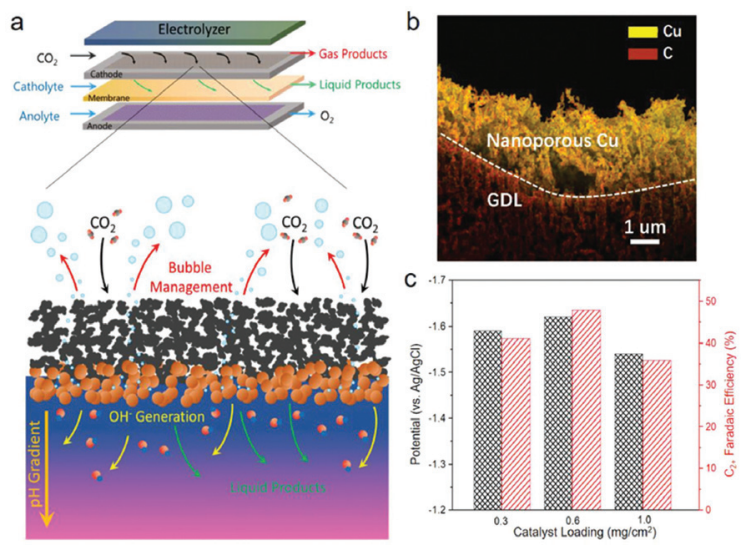

Fig. 3. $\mathrm{Cu}$ on $\mathrm{GDL}$ 전극을 활용한 수용액 기반의 이산화탄소 전해조 평가 Reproduced by Kim et al. Adv Mater 2018;30:1803111-8, with permission of John Wiley and Sons Publication [6].

Feng Jiao 연구팀은 2018년 수열합성을 통해 얻은 nanoporous 구조의 $\mathrm{CuO}$ 를 기체 확산 층 위에서 전 기화학적 환원 방법으로 nanoporous $\mathrm{Cu}$ on GDL을 제작하였고, 이를 전기화학적 이산화탄소 전해를 위 한 GDE로 활용하였다 (Fig. 3). ${ }^{6}$ 제작한 nanoporous $\mathrm{Cu}$ catalyst에 이산화탄소 기체를 직접 공급해줌으로 써 반응물의 물질 전달을 촉진시켜주었고, 결과적으로 $-0.67 \mathrm{~V}_{\mathrm{RHE}}$ 에서 $653 \mathrm{~mA} / \mathrm{cm}^{2}$ 의 높은 전류 밀도를 보 였다. 또한, $\mathrm{Cu}$ catalyst를 전극소재로 사용하여 $\mathrm{C}_{2+}$ 생 성물의 높은 선택도를 확보하였고, 전해질의 $\mathrm{pH}$ 가 상대 적으로 높은 $\mathrm{KOH}$ 용액을 사용하였을 때 우수한 이산화 탄소 전해조 성능을 보였다. 이는 $\mathrm{C}_{2+}$ 생성물의 선택도 를 결정하는 $\mathrm{C}-\mathrm{C}$ coupling reaction이 $\mathrm{pH}$ 가 높을수록 더 우호적인 것으로 확인되었다.

Jihun Oh 연구팀은 이산화탄소 전해조에 사용될 소 재로 polymethyl methacrylate replica 위에 제작 된 Au nanowire 촉매를 제작하였으며 반복 공정을 통 해 multi stacked Au nanowire (MS-Au NW)를 갖 는 GDE를 제작하였다 (Fig. 4). ${ }^{7}$ 기존의 H-type 전해 조에서 성능 평가 시 $\mathrm{MS}-\mathrm{Au} \mathrm{NW}$ cathode에서 높은 93\%의 CO 선택도를 보였으며, $\mathrm{Au} \mathrm{NW표면에서의} \mathrm{높은}$ high-index plane과 grain boundary 비율의 효과로 확인되었다. 또한, $\mathrm{MS}-\mathrm{Au} \mathrm{NW}$ 전극의 $\mathrm{3D}$ 구조는 고 

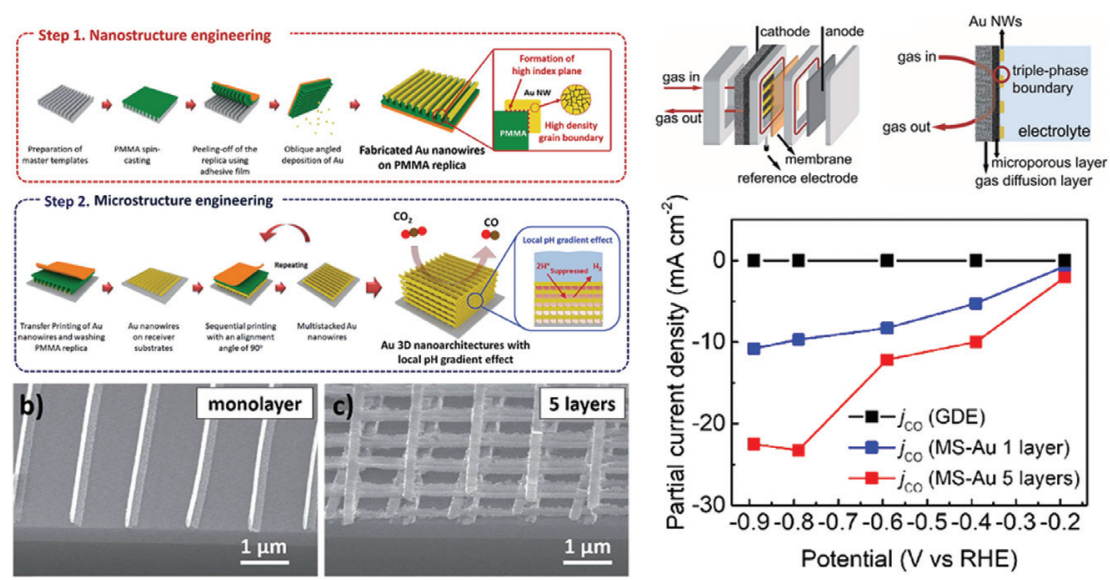

Fig. 4. MS-Au NW 전극 제작 과정 및 전극을 활용한 수용액 기반의 이산화탄소 전해조 평가 Reproduced by Kim et al. J Mater Chem A 2019;7:6045-52, with permission of Royal Society Chemistry Publication [7].
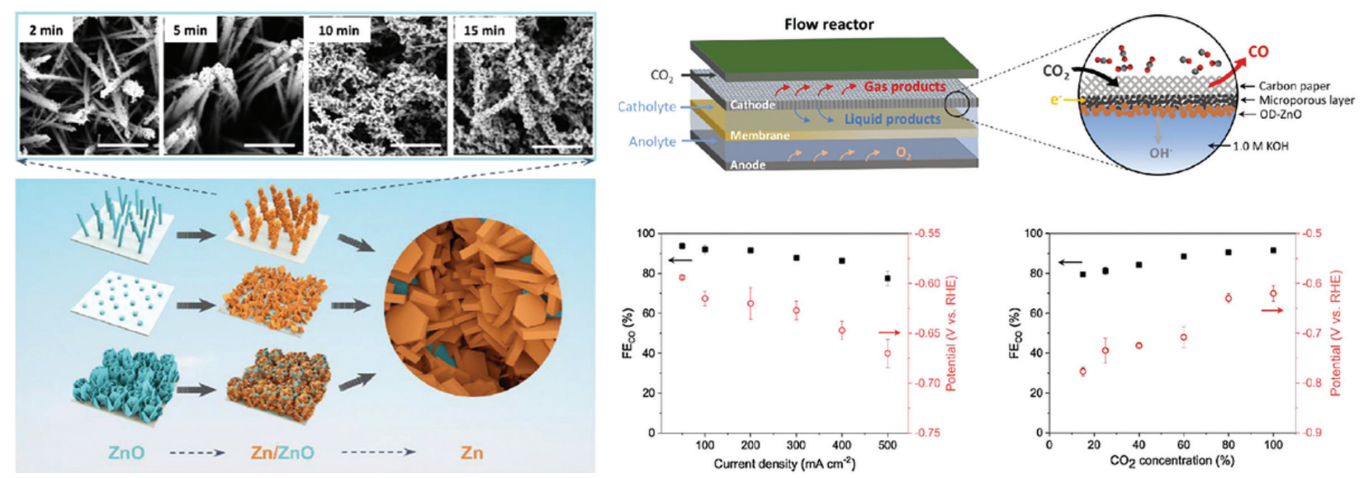

Fig. 5. ZnO 전극 제조 단계 및 전극을 활용한 수용액 기반의 이산화탄소 전해조 평가 Reproduced from Kim et al. Appl Catal B: Environ 2020;273:119060-9, with permission of Elsevier Publication [10].

전류 영역에서 높은 local-pH를 유도하였으며 경쟁 반 응인 $\mathrm{HER}$ 을 효과적으로 억제하였다. 제작한 $\mathrm{MS}-\mathrm{Au}$ $\mathrm{NW}$ 전극을 $\mathrm{GDE}$ 로 활용하였을 때 $-0.19 \mathrm{~V}_{\mathrm{RHE}}$ 의 전 압조건에서 $172.66 \mathrm{~A} / \mathrm{g}$ 의 $\mathrm{CO}$ 생성에 대한 높은 mass activity를 나타냈다. 이는 전극 구조 특성 상 반응물 기 체의 유입 및 전극 표면으로의 확산이 용이하여 기존의 $\mathrm{H}$-type 전해조보다 더 높은 $\mathrm{CO}$ 생성에 대한 전류밀도 를 나타낸 것으로 확인되었다.

$\mathrm{Zn}$ 는 이산화탄소의 전기화학적 분해 시 $\mathrm{CO}$ 를 생성할 수 있으며 $\mathrm{Au}$ 나 $\mathrm{Ag}$ 를 대체할 수 있는 물질로 주목받고 있다. ${ }^{89}$ Zuttel 연구팀은 고온 공정을 통해 얻은 $\mathrm{ZnO}$ 를 GDL 위에 drop-casting 방법으로 제작 후 전기화학적 환원 반응을 통해 hexagonal 형태의 $\mathrm{Zn}$ 촉매를 제작하
였다 (Fig. 5). ${ }^{10)} \mathrm{ZnO}$ 의 전기화학적 환원 과정은 촉매 구조의 변형을 이끌었을 뿐만 아니라 촉매의 활성 면적 을 증가시켜 이산화탄소 전해 시 우수한 성능을 보였다. 제작한 $\mathrm{ZnO}$ 전극 촉매를 $\mathrm{GDE}$ 을 기체 공급 기반의 이산 화탄소 전해조의 cathode로 활용한 결과, $200 \mathrm{~mA} / \mathrm{cm}^{2}$ 의 전류 밀도 조건에서 $91.6 \%$ 의 $\mathrm{CO}$ 생성에 대한 효율을 보였다. 이는 전극의 넓은 활성 면적과 더불어 porous 한 전극의 구조로 인하여 이산화탄소의 물질 전달 제한 을 극복하여 나타난 결과로 보고 있다.

하지만, $\mathrm{pH}$ 가 높은 전해질을 사용할 경우 cathode와 전해질 사이에서 탄산염이 형성되고 GDL의 기공을 막 기 때문에 전해조 구동에 대한 안정성 문제에 악영향을 미칠 수 있다. 또한, 고전압의 구동 조건에서, 전해질이 


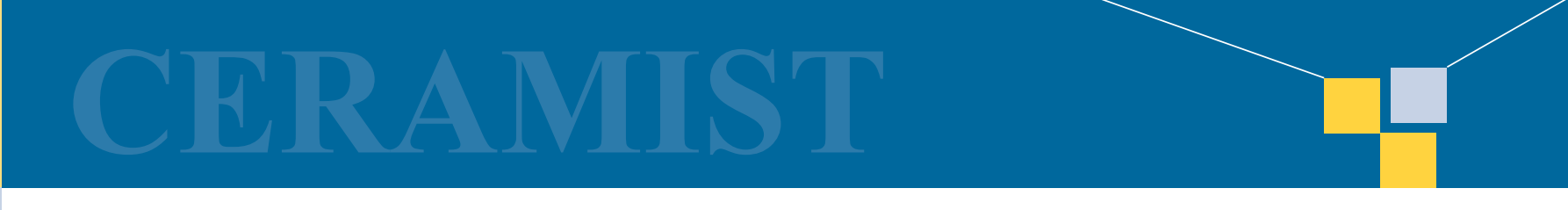

\section{특 집 표 김준형, 안상현}

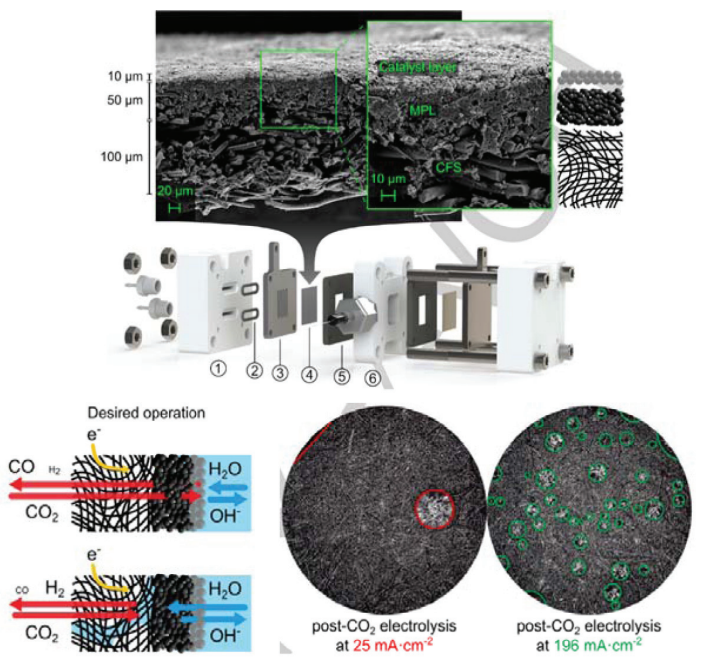

Fig. 6. 전해질층 존재에 따른 carbon flooding현상 Reproduced by Kim et al, ACS Energy Lett 2021;6:33-40, with permission of Royal Society of Chemistry Publication [11].

기체 확산 층으로 넘어가는 flooding현상이 발생할 수 있다. 일반적으로 GDE는 탄소 기반의 GDL이 사용되는 데, flooding현상이 일어나면 GDL의 wettability가 상 승하여 부반응인 HER이 발생한다. Fikile R. Brushett 연구팀의 연구 결과에 따르면, 염기성 기반의 전해질과 탄산염 형성에 따른 음극의 높은 알칼리도는 전해질의 flooding 현상이 가속화되는 것으로 밝혀졌다. ${ }^{11)}$ 또한, 전기화학적 환원반응 시 과전압에 의한 flooding 현상이 진행되는 것으로 나타났다. 이는 고전압 영역에서 구동 시, GDL의 wettability가 증가하고, 결과적으로 GDL과 전해질의 접촉면적이 넓어져 onset potential이 높아지 고 HER이 발생하는 것으로 확인되었다. ${ }^{12)}$ Bare GDL, $\mathrm{Ag} / \mathrm{GDL}$ 그리고 $\mathrm{Ag} / \mathrm{PTFE}$ 를 활용하여 기체 확산 전극 의 구조에 따른 flooding현상의 차이를 비교해본 결과, bare GDL과 $\mathrm{Ag} / \mathrm{GDL}$ 전극은 $-0.85 \sim-0.6 \mathrm{~V}_{\mathrm{RHE}}$ 의 범위에서 HER에 대한 onset potential이 확인된 반 면에, $\mathrm{Ag} / \mathrm{PTFE}$ 전극은 이보다 더 낮은 potential에 서 HER이 발생하였다. 이는 polytetrafluoroethylene (PTFE)의 방수 효과로 인하여 GDL으로의 flooding현 상을 방지하였고 전해질과의 접촉면적을 최소화하여
$\mathrm{HER}$ 활성이 억제된 것으로 확인되었다. 이산화탄소 전 해조의 구동전압의 세기가 증가할수록 기체 확산 전극 으로의 flooding현상이 점차 증가하는 것으로 확인되었 다. $-0.68 \mathrm{~V}_{\mathrm{RHE}}$ 의 전압을 가했을 경우, 대략 60 분 후 GDL의 flooding현상이 시작되었고, 150 분 후에 전해질 로 완전이 침수되었다. Flooding의 발생 시점은 전압이 감소할수록 더 빨라졌고 이는 GDL에 대한 XPS 분석을 통해서 확인해 보았을 때, PTFE의 degradation이 원 인으로 밝혀졌다. ${ }^{13)}$ 위의 실험 결과를 토대로, 전해질의 flooding현상을 최소화하고 전기화학적 이산화탄소 전 환에 대한 활성을 증대하기 위해서 전극 촉매의 활성 개 선이나 GDL의 물성 변화에 대한 연구가 필요하다.

Tierui Zhang연구팀은 silane/plasma 처리를 통하 여 $\mathrm{Au} / \mathrm{C}$ 의 wettability를 조절하고 이에 따른 이산화 탄소 전해에 대한 성능 변화를 연구결과로 보고하였다 (Fig. 7). ${ }^{14)}$ Silane/plasma 처리 시간에 따른 $\mathrm{Au} / \mathrm{C}$ 전극 의 contact angle을 비교해보았을 때, 처리 시간이 증 가할수록 contact angle이 감소하는 것으로 확인되었 고 친수성이 증가하였다. Silane/plasma 처리를 진행 하지 않은 $\mathrm{Au} / \mathrm{C}-\mathrm{F}$ 전극의 경우, 촉매와 전해질 사이의 매우 불안정한 접촉 성질로 인하여 대략 6 시간의 이산화 탄소 전해에 대한 낮은 구동 안정성을 보임과 동시에 낮 은 $\mathrm{CO}$ 생산 효율을 보였다. 반면, $\mathrm{Au} / \mathrm{C}-0.5$ 전극의 경 우, GDL의 적절한 수준의 친수성을 보이며 높은 구동 안정성을 확보할 수 있었다. 하지만, silane/plasma 처 리 시간 증가에 따른 GDL의 친수성 강화는 전해질의 flooding을 가속시키고 GDL의 기공을 막아 이산화탄소 전해에 대한 성능과 선택도를 낮추는 것으로 보였다.

Edward H. Sargent연구팀은 소수성을 갖는 GDL층 을 활용하여 이산화탄소 전해조 구동 시 ethylene에 대 한 높은 선택도와 150 시간 이상의 장기성능을 확보하 였다. ${ }^{15)}$ 일반적으로 $\mathrm{GDE}$ 은 탄소 기반의 지지체, micro porous layer (MPL) 그리고 촉매층으로 구성되어 있 다. 탄소 분말과 $\mathrm{PTFE}$ 로 이루어진 MPL은 평평하고 강 한 계면을 형성하여 촉매층과 지지체 사이의 접촉 저항 을 줄여줄 뿐만 아니라 소수성의 PTFE로 인하여 액체와 기체를 분리해주는 중요한 역할을 할 수 있다. ${ }^{16,17,18)}$ 이 

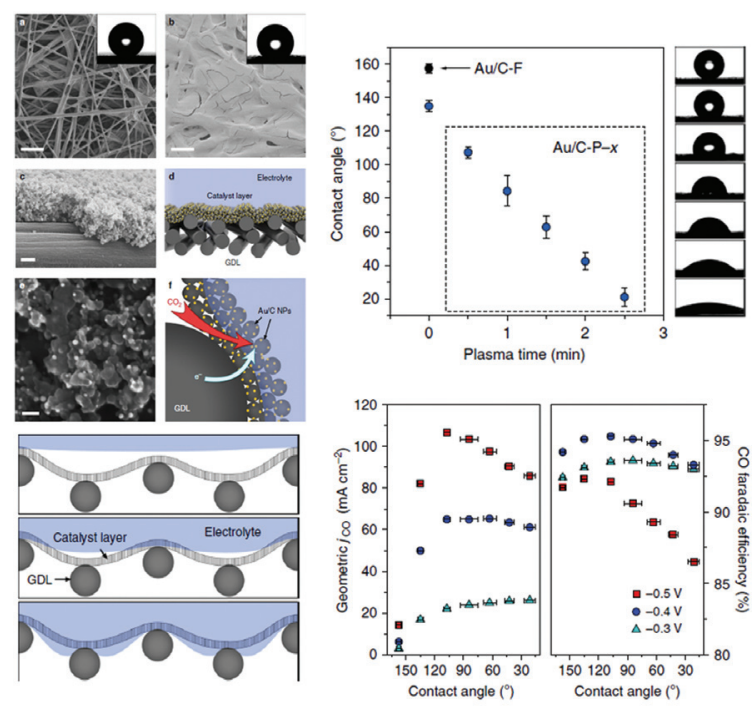

Fig. 7. Silane/plasma 처리를 통한 $\mathrm{Au} / \mathrm{C}$ 의 친수성 조절 Reproduced by Kim et al. Nat Commun 2020;11:302837, with permission of Springer Nature Publication [14].

때, $\mathrm{PTFE}$ 의 함량을 조절하여 $\mathrm{GDE}$ 의 친수성을 조절할 수 있고 이를 통해 이산화탄소 전해에 대한 성능 변화를 이끌 수 있다. PTFE 처리되지 않은 $\mathrm{Ag} \mathrm{GDE}$ 와는 달리, $20 \mathrm{wt} \% \mathrm{PTFE}$ 가 함유된 Ag GDE에서 우수한 $\mathrm{CO}$ 생성 에 대한 전류 밀도를 나타냈고, SEM 이미지로 확인하였 을 때, PTFE로 인하여 GDL위에 $\mathrm{Ag}$ 촉매가 고르게 분 산됨을 확인하였다. 하지만, 과도한 $\mathrm{PTFE}$ 함량은 $\mathrm{GDE}$ 내부에 비전도성 물질의 비율이 증가하게 되어 전하전 달에 대한 저항이 증가한다. ${ }^{19)}$ 위의 연구결과로써 $\mathrm{GDE}$ 를 구성하는 부분과 그에 대한 함량이 고전압에서 구동 되는 기체 공급 기반의 이산화탄소 전해 기술의 성능에 중요한 영향을 미칠 것으로 예상된다.

한편, 기체 공급 기반의 이산화탄소 전해조 구동 시, 공급되는 이산화탄소 기체와 전해질의 hydroxide ion 이 결합하여 탄산염을 형성하는 $\mathrm{CO}_{2}$ neutralization현 상이 발생할 수 있다. ${ }^{20)}$ 이는 공급되는 이산화탄소 기체 의 활용도를 낮출 뿐만 아니라 탄산염 형성에 따른 GDL 의 기공 막힘 현상이 발생하여 이산화탄소 전해에 대 한 성능을 저하시킬 수 있다. 또한, anion exchange membrane (AEM)을 활용하여 이산화탄소 전해조 를 구동할 경우, 형성된 탄산염이나 이산화탄소 전해

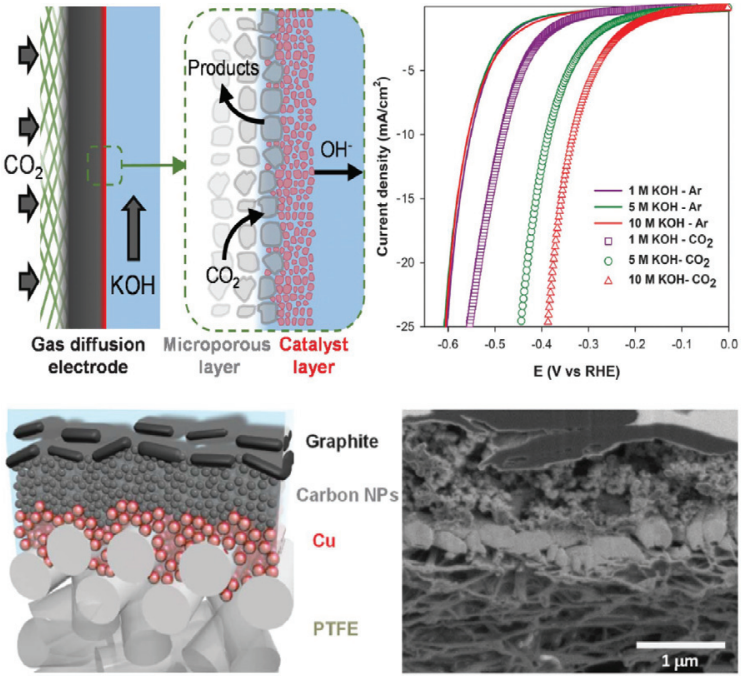

Fig. 8. 소수성 기체확산층의 flooding 현상 방지 Reproduced by Kim et al. Science 2018;360:783-7, with permission of The American Association for the Advancement of Science Publication [15].

로 인해 생성된 acetate, formate 등의 음이온이 분리 막을 통과하여 anode로 넘어가는 crossover 문제가 발 생할 수 있다. ${ }^{20)}$ Brian Seger연구팀의 연구결과에 따 르면, 이산화탄소 기체를 기존 $45 \mathrm{ml} / \mathrm{min}$ 의 유량으 로 음극에 주입했음에도 불구하고 대략 $42 \mathrm{ml} / \mathrm{min}$ 만 이 gas outlet에서 검출되었다 (Fig. 9). ${ }^{21)}$ 이는 이산 화탄소의 neutralization현상으로 탄산염이 생성되었 고, 생성된 탄산염이 anode로 넘어간 후 proton과 다 시 반응하여 이산화탄소로 배출되는 것이 확인되었다. 뿐만 아니라, anolyte에서 이산화탄소 전해 시 생성되 는 formate와 acetate가 검출되는 것으로 보아 $\mathrm{AEM}$ 활용 시 product crossover문제를 막을 수 없는 것으 로 예상된다. Andreas Zuttel연구팀 또한 AEM을 활용 한 이산화탄소 전해조 구동 시 product crossover현상 을 발견하였다. ${ }^{22)}$ 액체 생성물의 GDL 또는 AEM으로의 migration으로 인하여 이산화탄소 전해에 따른 총 생 성 효율이 $100 \%$ 를 만족하지 못하였다. 이는 acetone이 나 acetaldehyde같은 휘발성인 강한 생성물은 GDL으 로 확산되는 반면 acetate나 formate같은 음이온 생성 물은 $\mathrm{AEM}$ 을 통과하여 anolyte로 넘어간 것으로 확인 

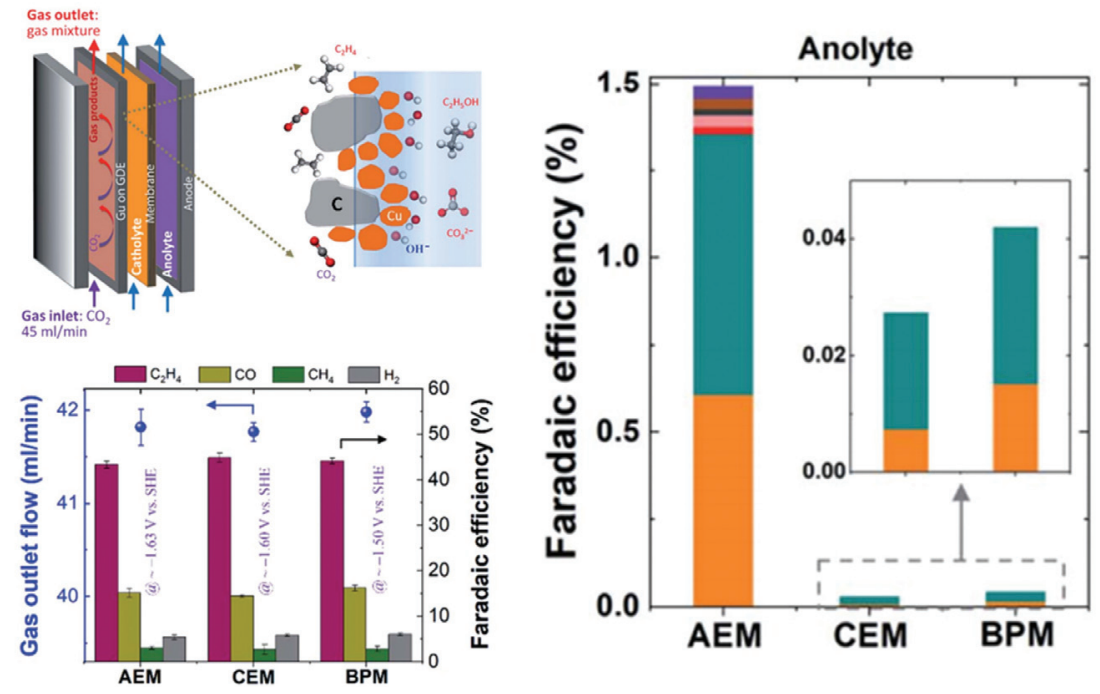

Fig. 9. Membrane 종류에 따른 생성물 crossover현상 Reproduced by Kim et al. Chem Sci 2020;11:8854-61, with permission of Royal Society Chemistry Publication [21].

되었다. 이산화탄소 기체나 전해질의 유량을 조절하여 crossover현상을 약화시킬 수는 있지만 완전히 방지하 는 것은 어려운 것으로 나타났다.

Bipolar membrane (BPM)의 활용은 이러한 생성물 들의 crossover문제를 방지할 수 있다. BPM은 AEM 과 cation exchange membrane (CEM)이 결합되어 있는 형태로써, 각 분리막의 접합층에서 물 분해과정 이 일어나고 발생한 proton과 hydroxide ion이 각각 cathode와 anode로 이동한다. 결과적으로 극성을 띄 고 있는 생성물의 electromigration을 막는 효과를 나 타낸다. 또한, proton과 hydroxide ion의 유입으로 인 해 전해질의 $\mathrm{pH}$ 를 유지시킬 수 있는 장점이 있다. 최 근 들어 Thomas E. Mallouk연구팀은 AEM과 BPM 의 사용에 따른 생성물 crossover현상을 보고하였다 (Fig. 10). ${ }^{23)} \mathrm{AEM}$ 을 활용하였을 때 높은 전류 밀도 구 간에서 상당량의 formate가 anode에서 검출되는 반 면, $\mathrm{BPM}$ 을 활용한 경우 crossover현상이 거의 나타나 지 않았다. Methanol이나 ethanol과 같은 중성 분자도 electromigration이 아닌 electroosmotic drag로 인하 여 분리막을 통과할 수 있지만 매우 적은 양으로 확인 되었다. $\mathrm{BPM}$ 을 활용하여 특정 생성물에 대한 생성효율 을 높일 수 있고 구동 안정성을 확보할 수 있다. K. C.
Neyerlin연구팀은 BPM을 활용하여 대략 $500 \mathrm{~mA} / \mathrm{cm}^{2}$ 의 formate 생성 전류 밀도를 나타낼 수 있는 이산화탄 소 전해조를 개발하였다 (Fig. 11). ${ }^{24)} \mathrm{BPM}$ 을 활용함과 동시에 catholyte층을 도입하여 전해질의 $\mathrm{pH}$ 를 유지하 는 buffer효과를 유도하였고, 대략 11 시간동안의 구동 안정성을 확보하였다. 또한, $25 \mathrm{~cm}^{2}$ 의 전극면적을 도입 하여 높은 formate 생성 전류 밀도를 확보하였다. 하지 만, 해당 연구결과에서도 나타나 있듯이, 이산화탄소 전 해조 구동에 따른 과전압을 분석해본 결과 $\mathrm{BPM}$ 의 비율 이 대략 $41 \%$ 차지하는 것으로 확인되었다. 이는 $\mathrm{BPM}$ 사이에서 발생하는 물 분해 과정과 ohmic 저항에 따 른 과전압으로 매우 높은 비율을 차지하고 있다. Curtis P. Berlinguette연구팀의 연구 결과에 따르면, 기체 공 급 기반의 이산화탄소 전해조를 구동할 때 필요한 전압 이 최소 $3.0 \mathrm{~V}$ 미만일 때 비로소 상업화할 수 있는 경제 성을 갖춘다고 보고하였다. ${ }^{25)}$ 뿐만 아니라, 전해질을 포 함하는 전해조의 경우 ohmic 과전압이 발생하고, 전류 밀도가 높아질수록 ohmic 저항에 따른 voltage drop 은 더 큰 비율로 증가한다. 이러한 과전압 발생은 수백 $\mathrm{mA} / \mathrm{cm}^{2}$ 의 전류 밀도를 요구하는 상업에서 활용하기에 는 부적합하다고 예상된다. 

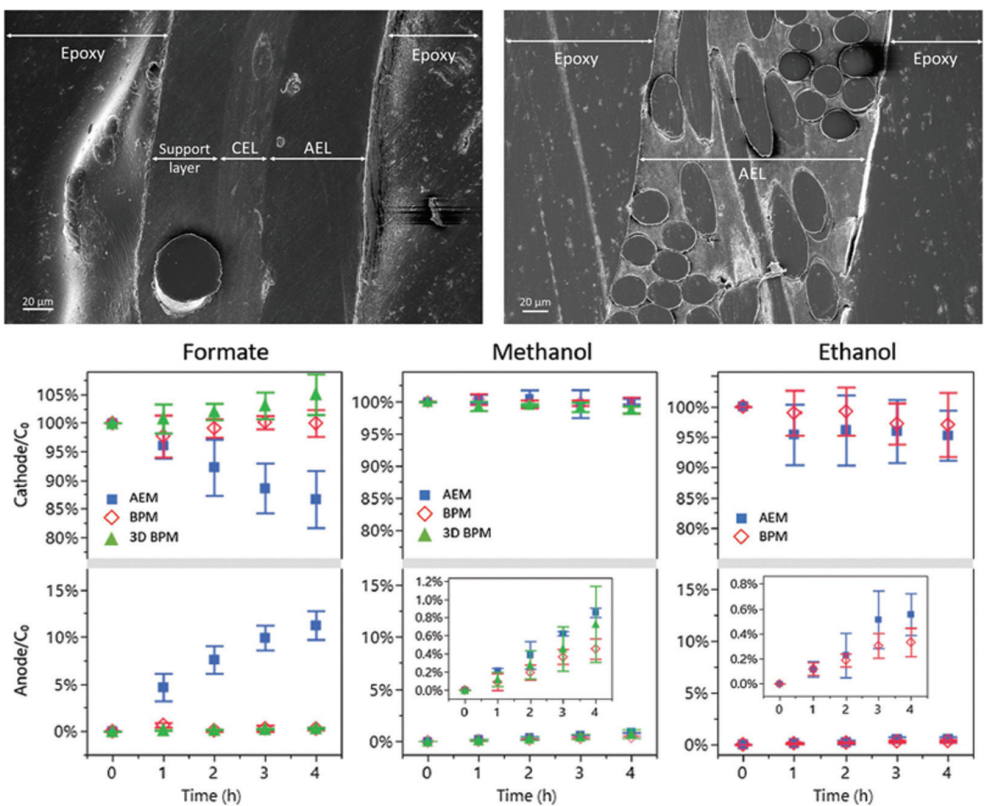

Fig. 10. BPM을 활용한 생성물 crossover현상 방지: BPM과 AEM의 SEM 이미지와 nembrane에 따른 crossover 생성물 분석 Reproduced by Kim et al. Adv Sustain Syst 2018;2:1700187-91, with permission of John Wiley and Sons Publication [23].
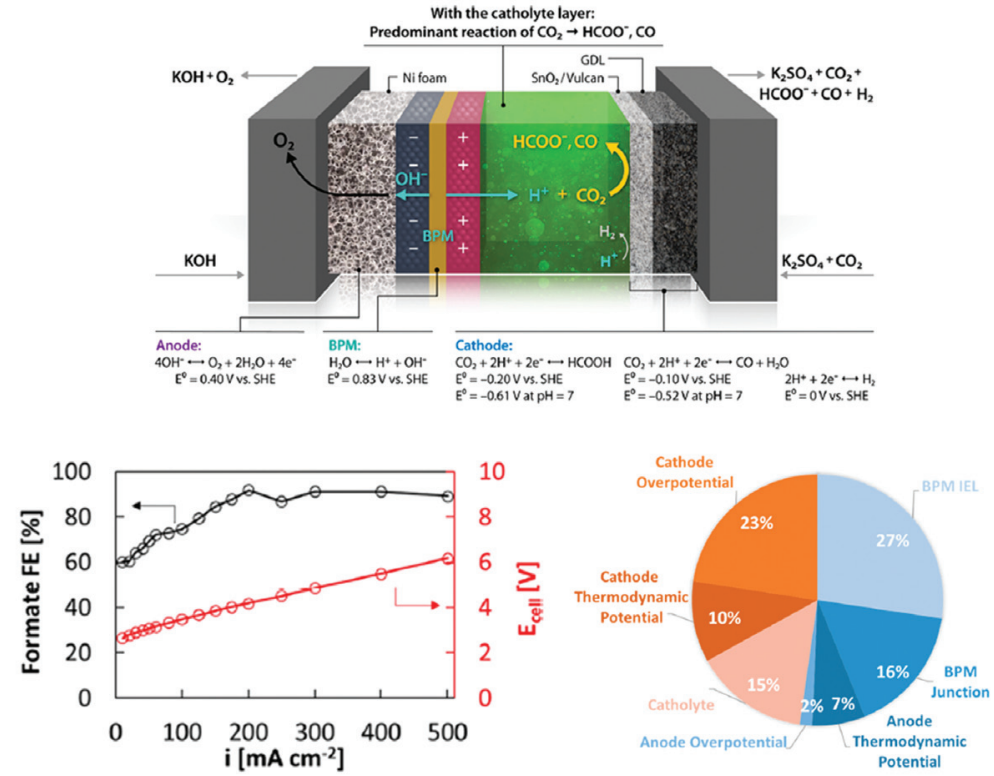

Fig. 11. BPM을 활용한 이산화탄소 전해조 성능 평가: 해당 전해조의 모식도, Formate 생성에 대한 성능과 전해조 구동에 필요한 과전압 분 석 Reproduced by Kim et al. ACS Energy Lett 2020;5:119060-9, with permission of American Chemical Society Publication [24].

\section{2-2. 막-전극 접합체 기반의 이산화탄소 전해조}

전해질층이 포함된 이산화탄소 전해조와 비교하여, 막-전극 접합체 기반의 이산화탄소 전해조 구성의 정
점은 전해질층의 부재와 동시에 전극 사이의 거리가 거 의 0에 가깝기 때문에 ohmic 과전압을 최소화할 수 있 다는 점이다. Curtis P. Berlinguette연구팀의 연구 결 


\section{특 집 ㅁㅃ 김준형, 안상현}
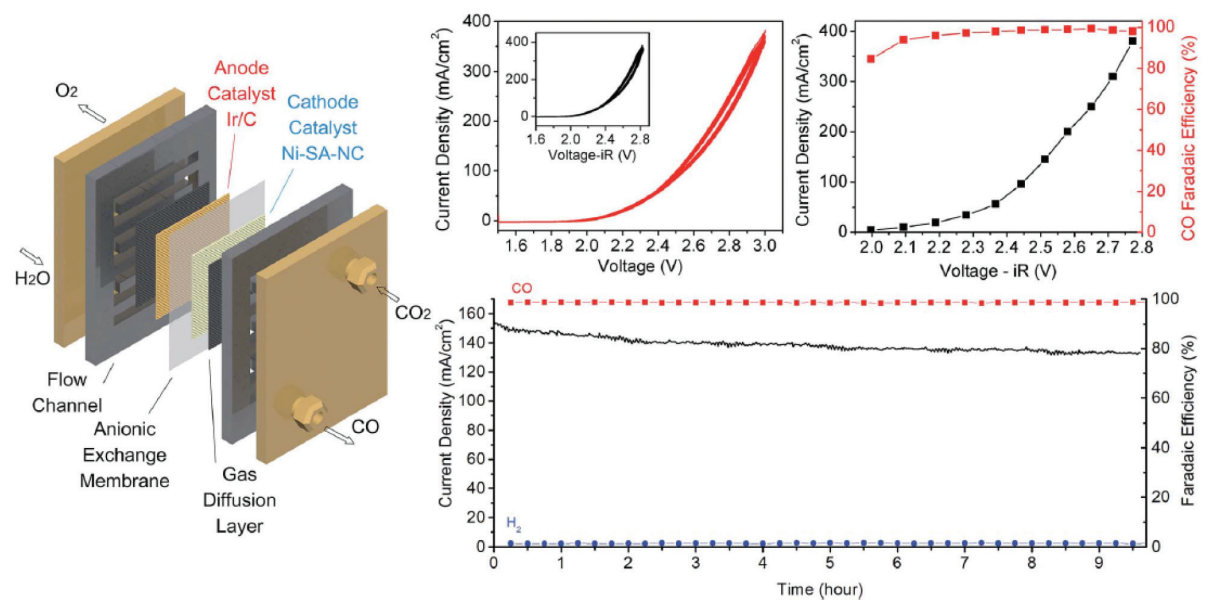

Fig. 12. Ni-SA-NC를 활용한 막-전극 접합체 기반의 이산화탄소 전해조 성능 평가 Reproduced by Kim et al. J Mater Chem A 2019;7:10651-61, with permission of Royal Society of Chemistry Publication [26].

과에서도 볼 수 있듯이, 전해질층에 대한 과전압은 없을 뿐더러 분리막에 대한 과전압도 다른 전해조 구성에 비 해 현저히 낮은 값을 나타낸다. ${ }^{25)}$ 때문에 최근 들어 막전극 접합체를 활용한 이산화탄소 전해조에 대한 연구 가 많이 진행되고 있다. Ki Tae Nam연구팀은 Ni-SA$\mathrm{NE}$ 전극 촉매를 제조하여 막-전극 접합체 기반의 이산 화탄소 전해조의 cathode로 활용하였고, $380 \mathrm{~mA} / \mathrm{cm}^{2}$ 의 $\mathrm{CO}$ 생성에 대한 높은 전류 밀도를 확보하였다 (Fig. 12). ${ }^{26)}$ Anode, cathode 그리고 membrane이 서로 분 리되어 있는 기존의 $\mathrm{H}$-type 전해조와 달리, 세 개 모 두 접합한 형태의 이산화탄소 전해조를 도입하여 성능 향상을 도모하였다. 또한, 가습된 기체 형태의 이산화 탄소를 cathode에 직접적으로 공급해줌으로써 촉매와 membrane 사이의 triple-phase boundary를 형성하 여 보다 많은 active site를 제공할 수 있었다. ${ }^{27)}$

Ki Tae Park연구팀은 막-전극 접합체 기반의 이산 화탄소 전해조를 활용하여 액체 생성물인 formate를 제 조하는데 성공하였다 (Fig. 13). ${ }^{28)}$ 또한, catholyte의 유 무에 따른 이산화탄소 전해조의 성능 차이를 제시하면 서 막-전극 접합체 구조의 장점을 강조하였다. 최대 25 $\mathrm{mA} / \mathrm{cm}^{2}$ 의 formate 생성에 대한 전류 밀도를 보여주는 기존의 $\mathrm{H}$-type 전해조와 달리, 막-전극 접합체 기반의 이산화탄소 전해조는 $52.9 \mathrm{~mA} / \mathrm{cm}^{2}$ 의 높은 전류 밀도 를 나타냈다. 또한, 48 시간의 장기성능 평가에서 대략
90\%의 formate 생성 효율을 유지하면서 높은 안정성을 보였다. 이는 기체 형태의 이산화탄소를 공급해줌으로 써 이산화탄소의 낮은 용해도 문제를 해결함과 동시에 전해질층의 부재로 구동전압을 크게 낮춘 효과로 예상 된다.

하지만, 막-전극 접합체 기반의 이산화탄소 전해 조 또한 $\mathrm{AEM}$ 을 활용할 경우 crossover현상을 피할 수 없다. Brian Seger연구팀의 연구결과에 따르면, $\mathrm{CO}_{2}$ neutralization현상으로 생성된 탄산염뿐만 아니라 부 산물인 포름산염이 membrane을 통과하여 anode에 서 발견되는 것을 확인하였다. ${ }^{29)}$ 이는 결과적으로 이 산화탄소의 utilization을 방해하여 이산화탄소 전해조 의 성능을 저하할 수 있다. 또한, 막-전극 접합체 기 반의 이산화탄소 전해조는 전해질층이 존재하지 않 기 때문에, anode로부터 넘어온 물을 분해하여 이산 화탄소 환원에 필요한 proton을 공급해준다. 때문에, cathode에 존재하는 물의 함량을 조절하는 것이 막전극 접합체 기반의 이산화탄소 전해조의 성능 향상에 중요한 역할을 한다. Curtis P. Berlinguette연구팀은 membrane의 물성과 cathode의 PTFE 함량 조절을 통 해 cathode로 유입되는 물의 flux를 계산하고 cathode flooding현상을 예측하였다 (Fig. 14). ${ }^{30)}$ High water uptake membrane은 anode에서 cathode로 유입되 는 물의 양을 억제하였고 결과적으로 높은 $\mathrm{CO}$ 생성 효 

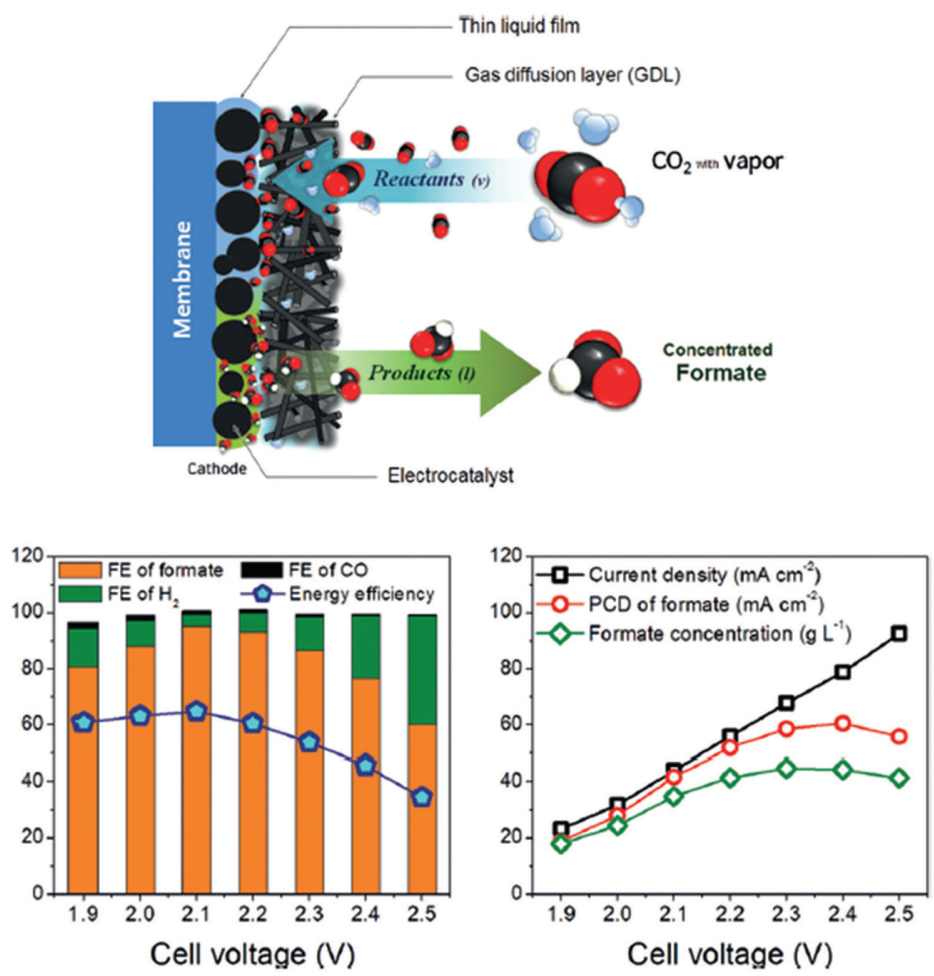

Fig. 13. Sn 전극을 활용한 막-전극 접합체 기반의 이산화탄소 전해조 성능 평가 Reproduced by Kim et al. Angew Chem Int 2018;57:6883-87, with permission of John Wiley and Sons Publication [28].

율과 전류 밀도를 보였다. 반면, low water uptake membrane은 cathode로의 과도한 물의 유입으로 인 하여 flooding현상에 따른 HER이 과도하게 진행되었 다. 하지만, $100 \%$ 가 넘는 높은 water uptake 능력의 membrane은 swelling현상으로 인하여 약한 기계적 강 도를 갖기 때문에 전해조의 구동 안정성에 악영향을 미 칠 수 있다. ${ }^{31,32)}$ 한편, 막-전극 접합체 사이에서 발생하 는 diffusion, electroosmotic drag, back convection 등을 고려하여 물의 net flux를 계산해보았을 때, 200 $\mathrm{mA} / \mathrm{cm}^{2}$ 의 전류 밀도 기준, cathode로 유입되는 물의 flux가 이산화탄소 전해에 필요한 $5 \mathrm{mg} / \mathrm{cm}^{2} \cdot \mathrm{h}$ 보다 많을 경우 cathode의 flooding현상이 발생하였다. 이 는 water uptake능력이 작고 얇은 membrane을 사용 할 경우 그리고 cathode의 hydrophobicity가 높을수록 flooding현상을 방지할 수 있다고 보고하였다.

\section{3. 결론}

지구온난화 현상이 급격하게 심각해지고 있는 상황에 서 대기중 이산화탄소의 농도를 줄이고자 많은 연구가 진행되고 있다. 그 중에서 전기화학적으로 이산화탄소 를 전환하고 이를 통해 유용한 연료를 생산하는 기술이 주목받고 있다. 이 이산화탄소 전해 기술의 경제성을 위 해 기체 형태의 이산화탄소 공급이 가능한 전해조 개발 에 대한 연구가 활발히 이루어지고 있다. 본지에서는 기 체 공급 기반의 이산화탄소 전해조 기술의 연구 동향에 대해서 소개하였다.

기존의 수용액 기반의 이산화탄소 전해조는 이산화탄 소의 낮은 용해도로 인하여 전극 표면으로의 물질 전달 이 제한되는 반면, 이산화탄소 기체의 직접적인 공급이 가능한 전해조의 경우 반응물의 물질 전달 문제를 극복 할 수 있기 때문에 보다 높은 생성물에 대한 전류 밀도 를 나타낼 수 있다. 또한, 이산화탄소 전해조의 형태나 

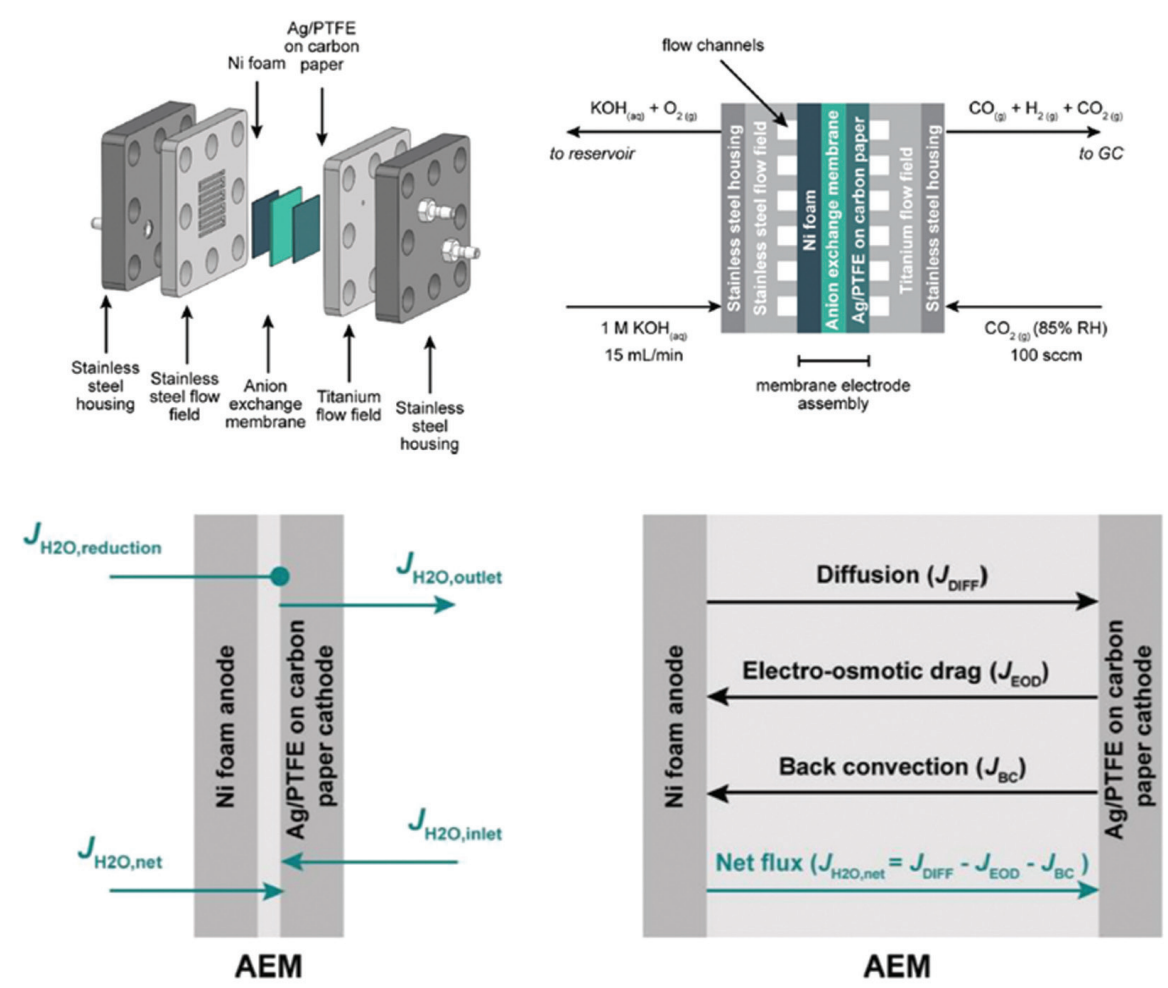

Fig. 14. Ag/PTFE 전극을 활용한 막-전극 접합체 기반의 이산화탄소 전해조 성능 평가. Reproduced by Kim et al. ACS Energy Lett 2020;5:1612-18, with permission of American Chemical Society Publication [30].

전극의 구조에 따라 전해조의 활성과 생성물의 선택도 를 조절할 수 있다. 하지만, cathode의 flooding현상이 나 생성물의 crossover현상 같은 성능을 저하시키는 문 제점들은 아직까지 해결해야할 부분으로 남아있다.

\section{REFERENCES}

1. T. R. Karl, and K. E. Trenberth, "Modern Global Climate Change," Science, 302 [5651] 1719-23 (2003).

2. J. D. Shakun, P. U. Clark, F. He, S. A. Marcott, A. C. Mix, Z. Liu, B. Otto-Bliesner, A. Schmittner, and E. Bard "Global warming preceded by increasing carbon dioxide concentrations during the last deglaciation," Nature, 484 [7392] 49-54 (2012).

3. M. Aresta, and A. Dibenedetto, "Utilisation of $\mathrm{CO}_{2}$ as a chemical feedstock: opportunities and challenges." Dalton Transactions, [28] 2975-92 (2017).

4. T. Burdyny, and W. A. Smith, " $\mathrm{CO}_{2}$ reduction on gasdiffusion electrodes and why catalytic performance must be assessed at commercially-relevant conditions,"
Energy \& Environ. Sci., 12 [5] 1442-53 (2019).

5. D. M. Weekes, D. A. Salvatore, A. Reyes, A. Huang and C. P. Berlinguette, "Electrolytic $\mathrm{CO}_{2}$ Reduction in a Flow Cell," Acc. Chem. Res., 51[4] 910-18 (2018).

6. J.-J. Lv, M. Jouny, W. Luc, W. Zhu, J.-J. Zhu and F. Jiao, "A Highly Porous Copper Electrocatalyst for Carbon Dioxide Reduction." Adv. Mater, 30 [49] 1803111 (2018).

7. M. Cho, J. M. Kim, B. Kim, S. Yim, Y. J. Kim, Y. S. Jung and J. Oh, "Versatile, transferrable 3-dimensionally nanofabricated Au catalysts with highindex crystal planes for highly efficient and robust electrochemical $\mathrm{CO}_{2}$ reduction," J. Mater. Chem. A, 7 [11] 6045-52 (2019).

8. J. Rosen, G. S. Hutchings, Q. Lu, R. V. Forest, A. Moore and F. Jiao, "Electrodeposited Zn Dendrites with Enhanced CO Selectivity for Electrocatalytic $\mathrm{CO}_{2}$ Reduction," ACS Catal., 5[8] 4586-91 (2015).

9. D. H. Won, H. Shin, J. Koh, J. Chung, H. S. Lee, H. Kim and S. I. Woo, "Highly Efficient, Selective, and Stable $\mathrm{CO}_{2}$ Electroreduction on a Hexagonal $\mathrm{Zn}$ 
Catalyst," Angew. Chem. Int., 55 [32] 9297-00 (2016).

10. W. Luo, Q. Zhang, J. Zhang, E. Moioli, K. Zhao and A. Züttel, "Electrochemical reconstruction of $\mathrm{ZnO}$ for selective reduction of $\mathrm{CO}_{2}$ to CO," Appl. Catal. B: Environ., 273119060 (2020).

11. M. E. Leonard, L. E. Clarke, A. Forner-Cuenca, S. M. Brown and F. R. Brushett, "Investigating Electrode Flooding in a Flowing Electrolyte, GasFed Carbon Dioxide Electrolyzer," ChemSusChem, 13 [2] 400-11 (2020).

12. T. Burchardt, "An evaluation of electrocatalytic activity and stability for air electrodes." J. Power Sources, 135 [1] 192-97 (2004).

13. D. J. Barker, D. H. Brewin, R. H. Dahm and L. R. J. Hoy, "The Electrochemical Reduction of Polytetrafluoroethylene," Electrochim. Acta, 23 [10] 1107-10 (1978).

14. R. Shi, J. Guo, X. Zhang, G. I. N. Waterhouse, Z. Han, Y. Zhao, L. Shang, C. Zhou, L. Jiang and T. Zhang, "Efficient wettability-controlled electroreduction of $\mathrm{CO}_{2}$ to $\mathrm{CO}$ at $\mathrm{Au} / \mathrm{C}$ interfaces," Nat. Commun., 11 [1] 3028 (2020).

15. C. -T. Dinh, T. Burdyny, M. G. Kibria, A. Seifitokaldani, C. M. Gabardo, F. P. García de Arquer, A. Kiani, J. P. Edwards, P. De Luna, O. S. Bushuyev, C. Zou, R. Quintero-Bermudez, Y. Pang, D. Sinton and E. H. Sargent, " $\mathrm{CO}_{2}$ electroreduction to ethylene via hydroxidemediated copper catalysis at an abrupt interface," Science 360 [6390] 783-7 (2018).

16. A. Z. Weber, and J. Newman, "Effects of Microporous Layers in Polymer Electrolyte Fuel Cells," J. Electrochem. Soc., 152 [4] A677-88 (2005).

17. M. J. Martínez-Rodríguez, T. Cui, S. Shimpalee, S. Seraphin, B. Duong and J. W. Van Zee, "Effect of microporous layer on MacMullin number of carbon paper gas diffusion layer," J. Power Sources, 207 91-100 (2012).

18. G.-G. Park, Y.-J. Sohn, T.-H. Yang, Y.-G. Yoon, W.-Y. Lee and C.-S. Kim, "Effect of PTFE contents in the gas diffusion media on the performance of PEMFC," J. Power Sources, 131 [1] 182-87 (2004).

19. E. Antolini, R. R. Passos and E. A. Ticianelli, "Effects of the cathode gas diffusion layer characteristics on the performance of polymer electrolyte fuel cells," $J$. Appl. Electrochem., 32 [4] 383-88 (2002).
20. M. Ma, E. L. Clark, K. T. Therkildsen, S. Dalsgaard, I. Chorkendorff and B. Seger, "Insights into the carbon balance for $\mathrm{CO}_{2}$ electroreduction on $\mathrm{Cu}$ using gas diffusion electrode reactor designs," Energy \& Environ. Sci., 13 [3] 977-85 (2020).

21. M. Ma, S. Kim, I. Chorkendorff and B. Seger, "Role of ion-selective membranes in the carbon balance for $\mathrm{CO}_{2}$ electroreduction via gas diffusion electrode reactor designs," Chem. Sci., 11 [33] 8854-61 (2020).

22. J. Zhang, W. Luo and A. Züttel, "Crossover of liquid products from electrochemical $\mathrm{CO}_{2}$ reduction through gas diffusion electrode and anion exchange membrane," J. Catal., 385 140-45 (2020).

23. Y. C. Li, Z. Yan, J. Hitt, R. Wycisk, P. N. Pintauro and T. E. Mallouk, "Bipolar Membranes Inhibit Product Crossover in $\mathrm{CO}_{2}$ Electrolysis Cells," Adv. Sustain. Syst., 2 [4] 1700187 (2018).

24. Y. Chen, A. Vise, W. E. Klein, F. C. Cetinbas, D. J. Myers, W. A. Smith, T. G. Deutsch and K. C. Neyerlin, "A Robust, Scalable Platform for the Electrochemical Conversion of $\mathrm{CO}_{2}$ to Formate: Identifying Pathways to Higher Energy Efficiencies," ACS Energy Lett., 5 [6] 1825-33 (2020).

25. D. Salvatore, and C. P. Berlinguette, "Voltage Matters When Reducing $\mathrm{CO}_{2}$ in an Electrochemical Flow Cell," ACS Energy Lett., 5 [1] 215-20 (2020).

26. H.-Y. Jeong, M. Balamurugan, V. S. K. Choutipalli, E.-s. Jeong, V. Subramanian, U. Sim and K. T. Nam, "Achieving highly efficient $\mathrm{CO}_{2}$ to $\mathrm{CO}$ electroreduction exceeding $300 \mathrm{~mA} \mathrm{~cm}^{-2}$ with single-atom nickel electrocatalysts," J Mater. Chem. A, 7 [17] 10651-10661 (2019).

27. T. Möller, W. Ju, A. Bagger, X. Wang, F. Luo, T. Ngo Thanh, A. S. Varela, J. Rossmeisl and P. Strasser, "Efficient $\mathrm{CO}_{2}$ to $\mathrm{CO}$ electrolysis on solid Ni-NC catalysts at industrial current densities," Energy \& Environ. Sci., 12 [2] 640-47 (2019).

28. W. Lee, Y. E. Kim, M. H. Youn, S. K. Jeong and K. T. Park, "Catholyte-Free Electrocatalytic $\mathrm{CO}_{2}$ Reduction to Formate," Angew. Chem. Int., 57 [23] 6883-87 (2018).

29. G. O. Larrazábal, P. Strøm-Hansen, J. P. Heli, K. Zeiter, K. T. Therkildsen, I. Chorkendorff and B. Seger, "Analysis of Mass Flows and Membrane Cross-over in $\mathrm{CO}_{2}$ Reduction at High Current Densities in an MEA-Type Electrolyzer," ACS Appl. 


\section{특 집 표 김준형, 안상현}

Mater. Interfaces, 11 [44] 41281-88 (2019).

30. A. Reyes, R. P. Jansonius, B. A. W. Mowbray, Y. Cao, D. G. Wheeler, J. Chau, D. J. Dvorak and C. P. Berlinguette. "Managing Hydration at the Cathode Enables Efficient $\mathrm{CO}_{2}$ Electrolysis at Commercially Relevant Current Densities," ACS Energy Lett., 5 [5] 1612-18 (2020).

31. J. Han, L. Zhu, J. Pan, T. J. Zimudzi, Y. Wang, Y.
Peng, M. A. Hickner and L. Zhuang, "Elastic LongChain Multication Cross-Linked Anion Exchange Membranes," Macromolecules, 50 [8] 3323-32 (2017).

32. J. Pan, S. Lu, Y. Li, A. Huang, L. Zhuang and J. Lu, "High-Performance Alkaline Polymer Electrolyte for Fuel Cell Applications," Adv. Funct. Mater., 20 [2] 312-19 (2010).
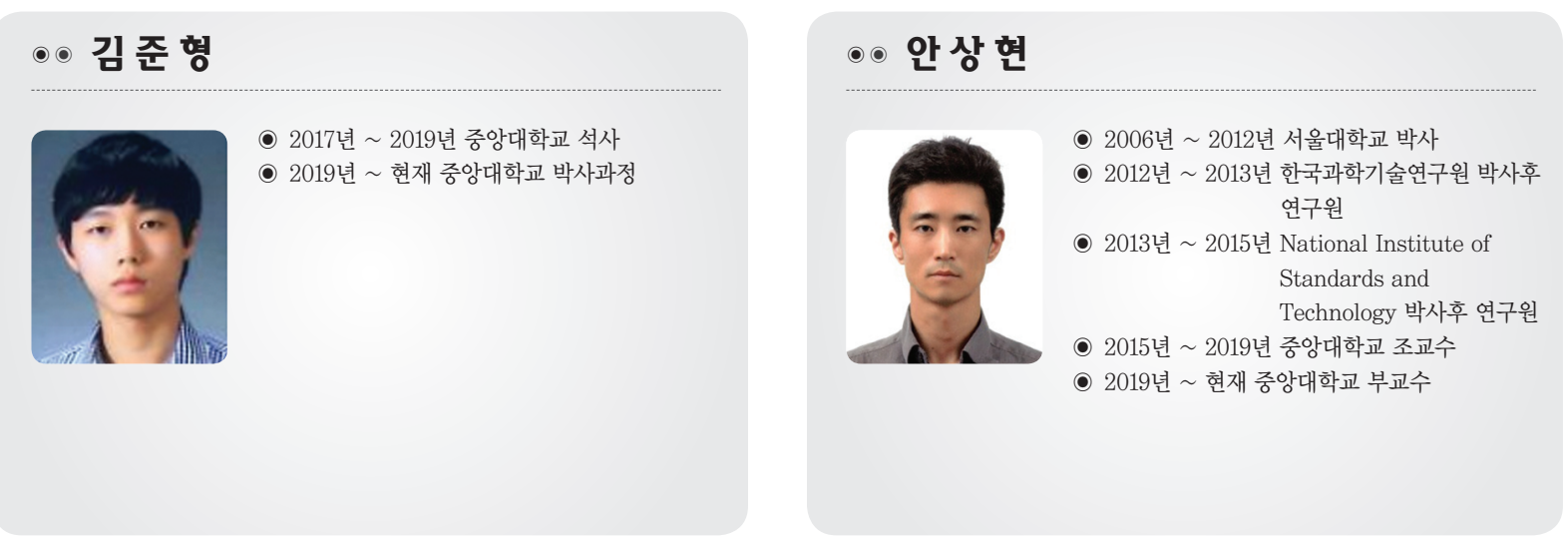